(C) INRA, EDP Sciences, 2006

DOI: $10.1051 /$ rnd:2006032

Review

\title{
Feeding and circadian clocks
}

\author{
Lissia PARDINI, Bertrand KAEFFER* \\ CRNH de Nantes, INRA - PHAN (UMR 1280), Rue de la Géraudière, BP 71627, \\ 44316 Nantes Cedex, France
}

(Received 18 November 2005; accepted 27 January 2006)

\begin{abstract}
The mammalian genome encodes at least a dozen of genes directly involved in the regulation of the feedback loops constituting the circadian clock. The circadian system is built up on a multitude of oscillators organized according to a hierarchical model in which neurons of the suprachiasmatic nuclei of the hypothalamus may drive the central circadian clock and all the other somatic cells may possess the molecular components allowing tissues and organs to constitute peripheral clocks. Suprachiasmatic neurons are driving the central circadian clock which is reset by lighting cues captured and integrated by the melanopsin cells of the retina and define the daily rhythms of locomotor activity and associated physiological regulatory pathways like feeding and metabolism. This central clock entrains peripheral clocks which can be synchronized by non-photic environmental cues and uncoupled from the central one depending on the nature and the strength of the circadian signal. The human circadian clock and its functioning in central or peripheral tissues are currently being explored to increase the therapeutic efficacy of timed administration of drugs or radiation, and to offer better advice on lighting and meal timing useful for frequent travelers suffering from jet lag and for night workers' comfort. However, the molecular mechanism driving and coordinating the central and peripheral clocks through a wide range of synchronizers (lighting, feeding, physical or social activities) remains a mystery.
\end{abstract}

\section{mammals / human / circadian rhythms / nutrients}

Abbreviations: SCN: suprachiasmatic nuclei, HNF: hepatocyte nuclear factor, TGF-alpha: transforming-growth-factor alpha, $\mathrm{NAD}(\mathrm{H}), \mathrm{NADP}(\mathrm{H})$ : nicotinamide adenine dinucleotide (phosphate), NO: nitric oxide.

Convention: For a better understanding, genes are written in italics, proteins in capitals.

\section{INTRODUCTION}

Light/dark cycles have rhythmed the life on Earth and created the selective conditions to integrate circadian rhythms in a genetic metabolic network functioning with a 24-h period of oscillations and called the circadian clock (or circadian oscillator). This clock synchronizes the circadian rhythmicity of some procaryotes (Cyanobacteria) and of plant or animal

\footnotetext{
* Corresponding author:

bertrand.kaeffer@nantes.inra.fr
}

eucaryotes from the cellular level to the organism [1-3]. The mammalian circadian system consists of at least two major oscillator systems, one entrainable by light called the central clock and located in the suprachiasmatic nuclei (SCN), and another by food which is anatomically and functionally distinct but of unknown location. The circadian system is built up on a multitude of oscillators organized according to a hierarchical model in which neurons of the suprachiasmatic nuclei of the hypothalamus may drive the central circadian clock 
and all the other somatic cells may possess the molecular components allowing tissues and organs to constitute peripheral clocks. At the molecular level, oscillators are molecules that are interacting to create a pacemaker. The pacemaker is an internal mechanism, which keeps time for the circadian clock by either coordinating or constructing rhythms (i.e. patterns of reoccurring events which can be loosely thought of as cycles).

In physiology, the circadian clock also called the circadian oscillator, is an internal device that keeps the body's time by driving and (or) coordinating a circadian rhythm. The concept has been integrated in the definition of homeostasis which is not only the capacity of a living structure to withstand and adapt its internal conditions to progressive or sudden changes of the environment but also to anticipate the occurrence of reoccurring events (i.e. reactive homeostasis; [4, 5]). The human circadian clock and its functioning in central or peripheral tissues are currently explored to increase the therapeutic efficacy of timed administration of drugs or radiation [6], and to offer better advice on lighting and meal timing useful for frequent travelers suffering from jet lag $[7,8]$ and for night workers' comfort.

This review presents the influence of feeding (temporal window of food access, meal frequency and composition) on the regulation of central and peripheral clocks.

\section{CIRCADIAN CLOCKS: A CENTRAL CLOCK TUNING THE NETWORK OF PERIPHERAL CLOCKS OR EQUIVALENT CLOCKS RUNNING LIKE A WEB?}

Somatic cells express the molecular components of circadian oscillators both in vivo and under artificial conditions of culture. These oscillators are able to integrate environmental cues called synchronizers (also entraining agent, time signal or Zeitgeber built on the German Zeit (time) and geber (giver)). Environmental cues with a circadian periodicity can entrain the circadian clockwork through sensory transducers relaying the signal to synchronize all the individual oscillators (Fig. 1). As demonstrated by modeling synchronization and rhythmicity of the circadian clock, stable synchronization depends on the synchronizer strength (its amplitude), if it is too weak there is no synchronization, if it is too strong the system loses its synchronization [9] and entrainment of an oscillatory system by another implies a gating process [10] but its biological means remain unknown.

Experimental recording of entrained circadian rhythms is highly dependent on both the strength of the synchronizer and the gating of the subjects' circadian systems. As shown by tissue culture and in vivo experiments, the inputs of the molecular clock are very diverse physico-chemical cues acting as synchronizers on signaling cascades integrated by period genes [11] and ranging from heat pulses in culture medium to the sudden exposure of cells to high serum concentration over $2 \mathrm{~h}$ [12]. However, the main in vivo synchronizer is believed to be the alternation of light and dark and many experiments have been realized on lighting and its capacity to drive circadian rhythms.

The duration of application of a synchronizer depends on the entrainment capacity of the oscillator (i.e. its intrinsic period and distribution around $24 \mathrm{~h}$ ). It is now considered to be between 1 and $2 \mathrm{~h}$ after in vivo experiments on the circadian wheel-running activity rhythm of hamsters presented with single or double light pulses [13] and on in vitro experiments on SCN neurons [14]. There are striking differences between the phase response curves to lighting of nocturnal mammals which have a dead zone for photoactivation 


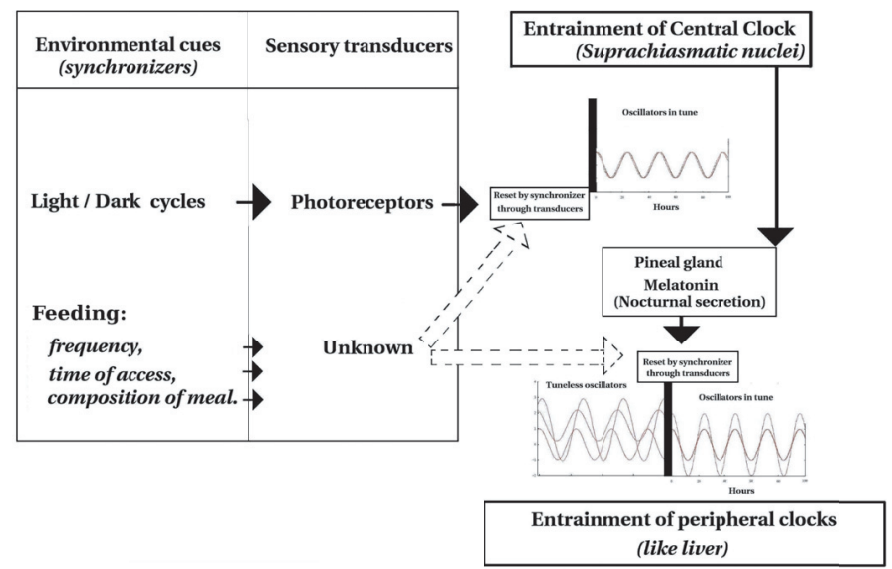

Figure 1. Relations between feeding and the circadian clocks. The central circadian oscillator has been evidenced in the suprachiasmatic nuclei [144] and called the central clock but the surgical deletion of these SCN changes does not always completely abolish the circadian rhythm of food intake, nor of central core temperature indicating that the anatomical location of the control centers driving these activities are still unknown [82,145-148]. Central and peripheral circadian clocks are entrained by external synchronizers allowing the organisms to react and anticipate reoccuring environmental variations with a circadian periodicity. Among these synchronizers, the light/dark cycles play a crucial role to entrain behavior and physiology of any mammal. Lighting cues are captured and integrated by melanopsin cells of the retina [149] which reset the central clock located in the suprachiasmatic nuclei and according to the diurnal or nocturnal nature of the mammalian species. The temporal windows of food access and the composition of the meal are considered synchronizers as powerful as the sun light $[102,103]$ and studies in circadian clock mutant mice have shown that the circadian clock network plays an important role in mammalian energy balance [128]. Feeding implies the frequency of food intake (experimentally defined as the frequency and the time or the temporal window of food access) and the nature of nutrients (the composition of food with directly metabolizable nutrients like D-glucose, fatty acids, L-glutamin or complex foods needing a digestive process by intestinal enzymes of the host or the resident microflora of the large intestine). The central clock has been found unresponsive to a temporal access of food in contrast with peripheral clocks like the one in the liver [112]. A hypocaloric ration was found able to entrain the central clock [125] as well as D-glucose [105] but more data are needed to allow an analysis of peripheral clocks functioning under these different foods. There are no data on the synchronizing effect of complex foods which are degraded into smaller compounds by digestive enzymes of the host or its microflora. The expression of clock components by cells of the digestive tract is progressively being demonstrated but the existence of a main peripheral clock driven by food, as crucial as the one located in the SNC, has not yet received any experimental demonstration.

during the subjective day and of diurnal mammals, like humans, which have no dead zone and can be entrained by light pulses during both subjective night and day $[15,16]$. As a whole, the circadian rhythmicity of the organism relies on a multitude of oscillators with a period close to but different from $24 \mathrm{~h}$. In that respect, organs and tissues are tuning each cellular oscillator to constitute its own peripheral 
clocks. However, the cell lineage providing the sensory transducers and the cellular pacemakers are unknown except for the central one (Fig. 1). In addition to circadian rhythms, there are other biological rhythms which are called ultradian by reference to cycles that are shorter than $20 \mathrm{~h}$ (i.e. the beating of the heart) and infradian which are cycles that are greater than $28 \mathrm{~h}$ (i.e. seasonal reproduction).

In this section, we will present the regulation of clock genes, the ontogenesis of SCN circadian rhythmicity (i.e. central clock) and the peripheral clockworks to underline the difficulties to demonstrate any influence of feeding on the circadian rhythms.

\subsection{Genes on which circadian clocks are running}

The mammalian genome encodes at least a dozen of genes directly involved in the regulation of the feedback loops constituting the circadian clock. The positive limb of the loop is driven by two transcription factors, CLOCK ([17, 18]; or a close analog called NPAS2 [19]) and BMAL1 $[18,20]$ which are basic Helix-Loop-Helix proteins with a PERARNT-SIM (PAS) domain; the equilibrium being post-translationally regulated by small ubiquitin modified proteins on BMAL1 through CLOCK-induced activity [21]. A first negative limb involves the protein regulators PERIOD 1 [22,23], PERIOD 2 [24,25] or PERIOD 3 [26]. These proteins do not directly bind to DNA but they have a PAS domain to build complexes with CRYPTOCHROME 1 or 2 [27-29]. Other proteins like NONO and WDR5 are able to modulate PERIOD activity [30]. The proteins CASEIN KINASE I epsilon or delta are involved in the turn-over of PERIOD molecules by phosphorylating these proteins and regu- lating their nuclear translocation [31-36]. A second negative limb involves members of the retinoic acid-related orphan nuclear receptors, RORA [37] and REVERB-ALPHA [38], which repress and modulate bmal1 expression. An additional loop of regulation driven by two Differentiated Embryon Chrondrocyte (DEC) proteins [39-41] has been proposed. These oscillator systems control the activity of clock-controlled-genes that function in the rate-limiting steps of various biological pathways [42-46].

In the absence of any environmental cue, the PERIOD2 protein is believed to reboost the circadian cycle by stimulating the transcription of bmall gene leading to the dimerization with CLOCK and to the reinduction of a new circadian cycle [47-54]. The circadian regulation of the period 2 gene has also been linked in vivo to tumor suppression and DNA damage response [55] or the regulation of bone formation by leptin [56]. Periodl and 2 genes are molecular candidates to study the adaptive response of the cellular metabolism with environmental stressors and they have been associated with the signaling pathway allowing a cell to anticipate and integrate changes in its normal environment.

In that respect, the promotor of the periodl gene may be a sensor and an integrator of physiological variations in the organism with the aim to adjust the clock to the environment $[57,58]$. Recently, Yamamoto et al. [59] showed that the promoter of the periodl gene contains at least a glucocorticoid-responsive element along with E-boxes for the binding of CLOCK:BMAL1 heterodimers related to the rhythmic expression of transcripts and with CAMP-responsive elements for periodl transient expression. The regulation of periodl gene is considered crucial for a quick adaptation to variations of environmental parameters $[30,60]$ and may be modulated by food intake [61]. 


\subsection{Circadian clockwork of suprachiasmatic nuclei: ontogenesis and role as the central clock}

The oscillator located in the suprachiasmatic nuclei (SCN; [144]) may be the center of the network and the unique oscillator entrainable by light/dark cycles. Observations realized on brain sections of human fetuses or born-dead and on newborns of primates suggest that there is a neuronal zone organized as suprachiasmatic nuclei fully functional at midgestation [62]. Likewise circadian rhythmicity has been detected in the fetus of the ewe by 2-deoxy-glucose incorporation [63]. The fetus (and consequently the neonate) may be entrained not only by maternal signals induced by light/dark cycles but also by the rhythmicity of nutrient supplies from the mother which may entrain rhythmic variations of blood parameters, of locomotor activities and of rectal body temperature [64].

In the mouse, neurons sensitive to light stimuli received by the retina are located in the ventrolateral SCN but the photic signal integration and the transmission of a circadian signal by the central clock is a complex process which may as well imply a second population of neurons nonsensitive to light and located in the dorsomedian SCN [65]. The oscillating system of these neurons may be synchronized by other cues, the central clock delivering a signal integrating the information from the two other neuronal populations. During the murine development as early as at the embryonic day 19, all clock genes (period1, period2, cryptochromel, bmall, clock) are expressed and circadian rhythmicity has been found at postnatal day 3 for period1, period2, cryptochrome1, bmall but not clock, the circadian rhythmicity of the latter being detected only at postnatal day 10 [66].

Studies on rat neonates and premature humans propose two main synchronizers: the light/dark cycles driving the suprachiasmatic nuclei oscillator and a synchronizer related to feeding and delayed for $12 \mathrm{~h}$. Molecular data obtained on murine embryos are in favor of the hypothesis that Mammal babies are born with a functional circadian system but have to tune their clocks with environmental synchronizers. As proposed by Weinert [64], the ontogenic development of the circadian system can be modified or imprinted by changing environmental conditions, the main consequence being on nursing of preterm infants who are reared in the relatively "timeless" conditions of neonatal intensive care nursery. However, direct comparisons between laboratory mammals and humans are difficult because of divergent milk compositions, maternal care or maturity of the babies. A clear-cut example is the acquisition of circadian rhythms driven by light/dark cycles. The babies of rats or mice born with closed eyelids remain relatively immature up to eyes opening in contrast with piglets or human babies born with open eyes that are considered as more mature.

In the adult, the two SCN exhibit rhythms in the uptake of 2-deoxyglucose, a marker of metabolic activity, in electrical activity, in spontaneous as well as lightinduced expression of immediate early genes, namely c-fos, a marker of neuronal activity, in the production of many peptides (e.g. of arginine vasopressin) and other rhythms [67]. The SCN are also driving the circadian regulation of D-glucose and insulin plasma levels [68]. Peripheral clocks may be entrained by signals issued by the SCN but could be uncoupled under conflictual conditions to follow the entrainement of synchronizers more relevant to their homeostasis.

\subsection{Properties of peripheral clocks}

In contrast with the central clock, the peripheral clocks could not be entrained 
by sun light [69-71] but are under the dependence of the central clock to perceive the photic signal through humoral factors like glucocorticoids [72-74], transforming growth factor alpha $[75,76]$ or prokineticin-2 [77]. However, the demonstration that the release of TGF-alpha or prokineticin-2 from the suprachiasmatic region may entrain the peripheral clock is still lacking. The phase of peripheral clocks is delayed with the central clock, however, the peripheral clocks are not synchronized, each one displaying its own rhythmicity specific of the tissue [78] entrainable by the environmental cues different from the one provided by the central clock [79]. For example, the expression of period 1 by rat fibroblasts is 4 to $8 \mathrm{~h}$ delayed with the central clock [80].

Surgical deletion of SCN and of surrounding brain regions alters but does not always completely abolish the circadian rhythm of food intake, nor the central core temperature $[82,145-148]$ indicating that up to now the anatomical location of the control centers driving these activities are still unknown. In addition, rats with surgical ablation of the SCN have an altered genetic expression of clock genes in the liver with a strong dampening or a total abolition of gene products coding for key metabolic pathways, cellular structural elements or elements involved in vesicular transport $[45,81]$. However, the rhythmic expression of genes implicated in the oscillating system (period2, bmall) persist even after this kind of lesion [45]. Thus, there is not only a single central clock but a network of circadian clocks, with the peripheral clocks being coupled to the central one but all retaining the capacity to uncouple with one another depending on the nature and strength of the synchronizers.

The existence of only one central clock is debated [82-84] suggesting that there is another clock able to receive the feeding signal, to integrate and dispatch the outcome to the rest of the organism and feed- back on central clock functioning. However the existence of such a clock driven by feeding, as crucial as the one located in the $\mathrm{SNC}$, is hampered by the scarcity of works on the characterization of clock compounds in the digestive tract. The presence of clock components has been demonstrated in the digestive tract (oral mucosa [85], liver [26, 86] and pancreas [87]. We have shown that the main molecular components (period1, period2, clock) of an intestinal clock are expressed by colonocytes of healthy human donors as well as by colon carcinoma cells $[88,89]$. Many rhythms which could be controlled by circadian clocks are observed in the intestine mainly cellular proliferation [90,91], migration [92] or apoptosis [93]. Circadian activities in the intestine are well known and concern the food intake, digestion (and associated enzyme activities), cellular proliferation, migration of epithelial cells along the physiological unit like crypts or villus, and apoptosis. Several genes have been described as regulated according to a circadian rhythmicity [2]: sodium/glucose cotransporter implicated in the absorption of dietary glucose and galactose, two transcription factors (hepatocyte nuclear factors HNF-1 alpha and beta), and uroguanylyl and guanyline which are intestinal receptors for guanylyl cyclase. Up to now, the liver has been the organ of choice to study peripheral clock functioning (Fig. 1) but a better understanding of circadian rhythms also implies integrating complex tissue architecture and interfacing with the external environment as in the lung or gut.

In summary, biological circadian oscillators are characterized by a stable oscillatory period of around $24 \mathrm{~h}$ and entrainability (the sensitivity of the oscillation's phase to periodic cue i.e. gating). Limit cycle oscillations are stable to minor perturbations of regulator concentrations and they persist over time even when the organism is not subjected to periodic driving forces (e.g. light exposure, feeding 
rhythms). However, circadian rhythmicity is also dependent on a lot of individual parameters like sex [94], adolescence status [95] or aging which has been shown to shorten the circadian period of older subjects in laboratory rodents $[96,97]$ but not in humans according to a study realized in fully controlled conditions on 11 young volunteers (23.7 years) and 13 old volunteers $(67.4 \mathrm{y})$ concluding that aging did not significantly modify the mean circadian periodicity of $24.18 \mathrm{~h}$ [98]. In addition, clocks must be buffered against changes in temperature which typically speed up or slow down macromolecular association but the mechanism of such a regulation is still unknown [99-101]. Part of the positive and negative masking effects of circadian rhythms driven by feeding have been addressed with rodents by taking advantage of the nocturnal nature of rats and mice which can be bred in constant darkness. However environmental cues are always interacting in the real world and it would be crucial to appreciate the resulting influence of the environment on the subjects' well-being. That means producing the catalogue of stromal cell lineages with their clock compound profiles, understanding the molecular regulation of clock genes and identifying, if any, cellular transducers and pacemakers.

\section{SYNCHRONIZATION OF CIRCADIAN CLOCKS BY FEEDING}

The hypothesis that feeding would be a synchronizer as powerful as light/dark cycles relies on many empirical observations realized on breeding units of laboratory rodents $[102,103]$ or on studies on consumers [104]. The water access, bulking effect (or capacity to induce satiety; [105]) or smell [106] are not considered as synchronizers and the influence of social ac- tivities on circadian rhythms are still being discussed [107].

By definition, feeding implies the frequency of food intake (experimentally defined as the temporal window of food access in or out of phase with the nocturnal or diurnal nature of the species including or not a fasting period) and the nature of nutrients (the composition of food with directly metabolizable nutrients like D-glucose, fatty acids, L-glutamin or complex foods needing a digestive process by intestinal enzymes or microflora of the large intestine). A simple cybernetic point of view can help to simplify the data in the field (Fig. 1). Feeding is not only a question of metabolizable energy, minerals, vitamins and growth factors provided at the right time and frequency, it also carries some information with different meanings decoded at the cellular genome level.

Experimenters have explored both sides of the problem and in the next section we will present the effects of temporal windows of food access and meal composition.

\subsection{The synchronizing effect of temporal windows of food access}

Rhythms of food intake present a high capacity to synchronize the rhythmicity of behaviors as well as the oscillating system of the peripheral clocks. In rats maintained in constant darkness or different lighting conditions, various circadian rhythms like the locomotor activity and the body temperature cycles are synchronized by the phase of food access [108, 109]. In addition the rhythmic expression of genes from the oscillating system (period1, 2, 3 and cryptochrome 1, rev-erb-alpha) and of output genes (like $d b p$ ) is reinitialized in the different organs and tissues but not in SCN $[79,87,110,111]$. After such a nutritional restriction, the phase delay is complete for periodl expression in the liver of transgenic rats and only partial in the 
lungs or non-existent in the SCN [112] suggesting a local effect or a tissue-specific effect of the synchronizer (Fig. 1). In addition, a "de-afferentiation" by capsicin (blocking of the parasymphatic system) did not abolish and did not alter the locomotor activity before a meal [113]. This uncoupling between central and peripheral rhythmicities, induced by nutrition, is founded on a study of mutated mice for the clock gene. These mice, maintained in constant darkness and fed with a restricted access to food, have a persistent altered locomotor activity, with a locomotor activity dependent of the SCN (consequently of the dark/light cycle) becoming arrhythmic [114]. These observations are in favor of a rapid and highly specific synchronization. This synchronization may imply organs or tissues directly entrained by the environmental cues like a nutritional stimulus influencing gut functioning. The phase of peripheral clocks can be modulated and totally uncoupled with the central clock through feeding (Fig. 1). Works in favor of the modulation of peripheral circadian clocks by feeding have been initiated on livers of transgenic rats maintained under nutritional restriction and have shown that hepatocytes are able to uncouple their circadian clocks of signals issued by the central clock, rephasing their oscillations on the rhythmicity of another synchronizer: the temporal window of food access [112]. In this study, transgenic rats had integrated the mouse periodl promoter linked to a luciferase reporter. The rhythmic expression of this so-called clock gene has been easily monitored in explant cultures of different organs (SCN, lung, liver) and related with the wheel-running activity of rats. Restricted feeding consists of 4 and 8-h time windows of food-access. The central clock (SCN) has been found unresponsive to a temporal access of food in contrast to peripheral clocks like the one in the liver [112]. Nevertheless, Miki et al. [115] have studied the total parenteral nutrition of rats suggesting that there is some feedback effect on the central clock. Indeed, while parenteral nutrition is given during the day in the rat, the period 2 expression is phase-advanced, in the liver as well as in the suprachiasmatic nuclei. This study is crucial because the nutritional intake is provided under free-running conditions, without external cues like visual perception or smell.

In humans, studies give contradictory results. In 1973, Reinberg et al. [116] showed that people working in moving working hours $(3 \times 8$ in rapid rotation) but with fixed meal times, had for those working at night, delayed peaks of plasmatic catecholamines or serotonin of more than $4 \mathrm{~h}$ with the day workers. More recently, Iraki et al. [117] and Bogdan et al. [118] showed that people following the Ramadan rite (meals are consumed at night for around a month) had an altered circadian profile for a lot of parameters like rates of insulin, glucose, calcium, gastrin but also of prolactin, cortisol, and melatonin. Nevertheless, a single meal containing high carbohydrate levels consumed either in the morning or in the evening has been found without an effect on the rhythm of melatonin suggesting that this temporal food restriction does not have enough synchronizing properties to modify the phase of the central clock [119]. In addition, chronic feeding of food with melatonin enhances the phase shifting response to triazolam in both young and old golden hamsters [120].

In our opinion, the main contribution in the field is the demonstration that feeding cycles in transgenic rats can entrain the liver clock independently of the suprachiasmatic nuclei [112]. However, Mendoza et al. [121] showed in mice that central circadian rhythmicity is partly influenced by feeding.

To summarize, animal studies are in favor of the hypothesis that there are at least two (or more) main circadian clocks integrating either photic signals or nutritional 
cues from the feeding rhythms but human studies on the synchronization of circadian rhythms by the frequency and times of meals are only at their beginning. Other works are trying to correlate the composition of meals with the circadian rhythms of physiology and behavior or to study the effects of metabolites with the advantage to relate molecular data on clock gene regulation with cellular catabolism and anabolism to provide a more integrated view of physiology and behavior.

\subsection{The synchronizing effect of the energetic value of meals}

Beside the influence of food intake rhythms, the energetic value may be implicated in the modulation of circadian rhythms $[122,123]$ even if, according to experiments on mice fed ad libitum, the lightentrainable pacemaker controls the period of the food-entrainable pacemaker [122]. The influence of the species' behavior has also been studied by comparing Syrian and Siberian hamsters suggesting that metabolic cues may directly influence the SCN [124]. In rodents, a caloric restriction triggers a phase advance of the altered locomotor activity, of hormonal peaks (melatonin, corticosterones), of body temperature [125] as well as the profile of night activity $[122,124,126]$. In addition, the composition of food in terms of caloric value has been found relevant to synchronize rats receiving chow as a meal. A threshold value of $22 \mathrm{kcal}(92 \mathrm{~kJ})$ has been proposed for a synchronizing effect of food on feeding of an entrained circadian oscillator; [105]. The influence of a hypocaloric food has also been studied by reducing the daily intake from $5 \mathrm{~g}$ of chow per day to $3.3 \mathrm{~g}$ of chow per day distributed at Zeitgeber Time 2, 10, 14, 22 (ZT 12 = lights off) recording phase advanced in the nocturnal pattern of activity by $1,3,1$ and $1 \mathrm{~h}$ [122]. By using Clock mutant mice, Challet et al. [127] showed that these animals are responsive to non photic phase-shifting leading the way to a recent demonstration that the energy balance of a meal can be influenced by the circadian clock and responsible in part for obesity [128].

The demonstration of the relations between feeding and circadian clocks has not been simplified with microarray analyses of mammalian cells. According to divergent publications, only $10 \%$ of the eucaryote transcriptome is believed to be clock-dependent $[67,129]$ leaving few if any metabolic pathways out of the control of clockwork but indicating that experimenters have to take into account both qualitative and quantitative variations of hundreds of transcripts with tissue specific profiles. In the rat, fasting triggers a modification of the rhythmic expression of 325 genes on 516 genes studied in the liver [78]. Thus even though a direct implication of circadian clock genes is not easy to unmask, these studies are in favor of a link between caloric restriction, circadian clocks, and physiological modifications.

Beyond the rhythms of food intake and the energetic value of a meal, D-glucose may have directly or indirectly an action on the regulation of the circadian clocks. Indeed, on SCN lesionized rats, the altered locomotor activity is delayed while the meal is replaced with D-glucose but this parameter is not modified if the meal is substituted by vegetal or mineral oil or by saccharine [123]. D-glucose may be directly implicated in the modulation of the circadian clocks since the reinitialization of the phase of locomotor activity by light in the mouse is attenuated with a reduced availability of D-glucose [130]. D-glucose was studied by intraperitoneal injection in order to directly study the extracellular concentration of glucose in the brain. Challet et al. [130] showed that glucose availability attenuates circadian responses to light in mice. Glucose utilization was 
blocked by 2-Deoxy-Glucose (0.4 M (or $550 \mathrm{mg} \cdot \mathrm{kg}^{-1}$ ) of glucose and 2DG) or $2 \mathrm{~g}$ glucose per $\mathrm{kg}$ by intraperitoneal injection. The effect of $30 \mathrm{~h}$ fasting and insulin injection have also been studied in parallel groups of mice.

Metabolites like D-glucose are both cellular fuel used to produce ATP and signaling molecules binding DNA on response elements to modulate gene transcription; the concentration and its variation are coding the message and correspond to the input synchronizer strength. By taking into account the metabolic status of the cell, i.e. the redox potential of $\operatorname{NAD}(\mathrm{H})$ and NADP $(\mathrm{H})$ cofactors (Nicotinamide adenine dinucleotide (phosphate)), it may be possible to explain how the nutrients, and in particular D-glucose, could be implicated in the regulation of the circadian clocks. Cellular catabolism of dietary Dglucose implies energy. This energy is provided by the oxidation of $\mathrm{NAD}(\mathrm{P}) \mathrm{H}$ cofactors and the liver NADH/NADPH ratios have the strongest in vivo circadian oscillations. In this model, the binding capacity of the CLOCK:BMAL1 complex to the DNA would be regulated by the redox status of $\mathrm{NAD}(\mathrm{H})$ and $\mathrm{NADP}(\mathrm{H})$ cofactors, the reduced form potentializating this binding and the oxidized one reducing it and the balance controlling the expression of clock controlled genes [131, 132]. A direct influence of NO, a known vasodilatator, has been found on the fixation of the CLOCK:BMAL1 on the E boxes distributed along DNA molecules both in the suprachiasmatic nuclei and in the external neural system. This fixation is under the influence of the NAD cofactors (i.e. their ratios) which are under the influence of oxygen and the metabolism of Dglucose. As a consequence, the D-glucose supply may have an inhibiting effect on the CLOCK:BMAL1 complex and could alter circadian clockwork.

In addition, metabolites like D-glucose are able to bind directly to DNA molecules in specific regions called response elements to modulate the transcription of some genes. The demonstration has been realized in vitro on cell lines of fibroblastic origin [133] and a similar effect of glucose on period genes have been reproduced on colon carcinoma cells [134].

In summary, a hypocaloric ration was found to entrain the central clock [125] as well as D-glucose [105] but more data are needed to allow an analysis of peripheral clocks functioning under different compositions of foodstuffs. There are no data on the synchronizing effect of complex foods which are degraded in smaller compounds by digestive enzymes of the host or its microflora. In addition, the influence of feeding on circadian rhythms may be tissue specific [78] with a strong influence on the clocks of the organs implied in the digestive process. Implication of nutrients (like short-chain fatty acids, the main energetic source for colonocytes [135] or L-glutamine, the main energetic source for the enterocyte [136]) in the tissular regulation of peripheral circadian clocks are yet to be explored.

\section{PERSPECTIVES}

The circadian clocks play a crucial role in the integration of various environmental cues (light, feeding, physical and social activities) or in the control of vital processes (cell division cycle, differentiation, apoptosis) and it may become possible to prove the existence of local and specialized circadian clocks in the processing and transmission of information coming from the environment. The role of clock genes in human physiology is progressively unraveled by relating behavioral and physiological trends with some genomic mutation. Familial advanced sleep phase syndrome [137, 138], delayed sleep phase syndrome and normal variations of morning larks and night owls 
phenotypes $[139,140]$ and diurnal preference [141] have been related with genomic mutation. Further studies realized to understand and manipulate feeding as a synchronizer of central and peripheral clocks might improve the well-being and health of two categories of people: Neonates born either premature or at term who have to organize their circadian rhythms $[64,142]$ in order to understand the acquisition of consolidated sleep, improve nursing practice and evaluate the impact of diet on the construction of circadian rhythms and its consequence on health of the future adult; the night or shift workers who now represent around $20 \%$ of the work force in our societies [143] and are highly concerned by comfort and healthy practices to recover from work efforts.

\section{ACKNOWLEDGEMENTS}

We thank for financial support the "Région Pays de la Loire", the "départements Alimentation Humaine et Biométrie Intelligence Artificielle" from INRA; the inter-EPST initiative in Bioinformatics and the Japanese society of chronobiology for a grant attributed to attend the first International Congress of Chronobiology held in Sapporo, September 2003. Part of this review has been published in the litterature section of Dr Lissia Pardini's PhD (October 29th, 2004, University of Nantes).

\section{REFERENCES}

[1] Dunlap JC. Molecular bases for circadian clocks. Cell 1999, 96: 271-290.

[2] Harmer SL, Panda S, Kay SA. Molecular bases of circadian rhythms. Annu Rev Cell Dev Biol 2001, 17: 215-253.

[3] Ladislas R. Les temps de la vie. Nouvelle Bibliothèque scientifique, éd Flammarion, 2002, pp 300.

[4] Moore-Ede MC. Physiology of the circadian timing system: predictive versus reactive homeostasis. Am J Physiol 1986, 250: R735-R752.
[5] Boissin J, Canguilhem B. Les Rythmes du vivant. Origine et contrôle des rythmes biologiques. Éditions CNRS/Nathan, 1998, pp 320 .

[6] Lévi F. From circadian rhythms to cancer chronotherapeutics. Chronobiol Int 2002, 19: $1-19$.

[7] Cho K. Chronic "jet lag" produces temporal lobe atrophy and spatial cognitive deficits. Nat Neurosci 2001, 4: 567-568.

[8] Comité consultatif de la médecine tropicale et de la médecine des voyages (CCMTMV). Syndrome du décalage horaire (Travel statement on Jetlag). Ministère de la santé du Canada, 2003, pp 4-8.

[9] Roenneberg T, Merrow M. Life before the clock: modeling circadian evolution. J Biol Rhythms 2002, 17: 495-505.

[10] Geier F, Becker-Weiman S, Kramer A, Herzel H. Entrainment in a model of the mammalian circadian oscillator. J Biol Rhythms 2005, 20: 83-93.

[11] Travnickova-Bendova Z, Cermakian N, Reppert SM, Sassone-Corsi P. Bimodal regulation of mPeriod promoters by CREBdependent signaling and CLOCK/BMAL1 activity. Proc Natl Acad Sci USA 2002, 99: 7728-7733.

[12] Kaeffer B, Pardini L. Clock genes of mammalian cells: practical implications in tissue culture. In Vitro Cell Dev Biol Anim 2005 41: 311-320.

[13] Best JD, Maywood ES, Smith KL, Hasting MH. Rapid resetting of the mammalian circadian clock. J Neurosci 1999, 19: 828-835.

[14] Asai M, Yamaguchi S, Isejima H, Jonouchi M, Moriya T, Shibata S, Kobayashi M, Okamura H. Visualization of mPer1 transcription in vitro: NMDA induces a rapid phase shift of mPer1 gene in cultured SCN. Curr Biol 2001, 11: 1524-1527.

[15] Jewett ME, Rimmer DW, Duffy JF, Klerman EB, Kronauer RE, Czeisler CA. Human circadian pacemaker is sensitive to light throughout subjective day without evidence of transients. Am. J. Physiol. 1997, 273: R1800-R1809.

[16] Duffy JF, Wright KP Jr. Entrainment of the human circadian system by light. J Biol Rhythms 2005, 20: 326-338.

[17] King D, Zhao Y, Sangoram A, Wilsbacher L, Tanaka M, Antoch M, Steeves T, 
Vitaterna M, Kornhauser J, Lowrey P, Turek F, Takahashi J. Positional cloning of the mouse circadian clock gene. Cell 1997, 89: 641-653.

[18] Gekakis N, Staknis D, Nguyen HB, Davis FC, Wilsbacher LD, King DP, Takahashi JS, Weitz CJ. Role of the CLOCK protein in the mammalian circadian mechanism. Science 1998, 280: 1564-1569.

[19] Reick M, Garcia JA, Dudley C, McKnight SL. NPAS2: an analog of Clock operative in the mammalian forebrain. Science 2001, 293: 506-509.

[20] Hogenesch JB, Gu YZ, Jain S, Bradfield CA. The basic-helix-loop-helix-PAS orphan MOP3 forms transcriptionally active complexes with circadian and hypoxia factors. Proc Natl Acad Sci USA 1998, 95: 5474-5479.

[21] Cardone L, Hirayama J, Giordano F, Tamaru T, Palvimo JJ, SassoneCorsi P. Circadian clock control by SUMOylation of BMAL1. Science 2005, 309: 1390-1394.

[22] Sun Z, Albrecht U, Zhuchenko O, Bailey J, Eichele G, Lee CC. RIGUI a putative mammalian ortholog of the drosophila period gene. Cell 1997, 90: 1003-1011.

[23] Tei H, Okamura H, Shigeyoshi Y, Fukuhara C, Ozawa R, Hirose M, Sakaki Y. Circadian oscillation of a mammalian homologue of the Drosophila period gene. Nature 1997 . 389: 512-516.

[24] Albrecht U, Sun ZS, Eichele G, Lee CC. A differential response of two putative mammalian circadian regulators mperl and mper2, to light. Cell 1997, 91: 1055-1064.

[25] Shearman L, Zylka M, Weaver D, Kolakowki L Jr, Reppet S. Two period homologs: circadian expression and photic regulation in the suprachiasmatic nuclei. Neuron 1997, 19: 1261-1269.

[26] Zylka MJ, Shearman LP, Weaver DR, Reppert SM. Three period homologs in mammals: differential light responses in the suprachiamatic circadian clock and oscillating transcripts outside of brain. Neuron 1998, 20: 1103-1110.

[27] Van der Horst G, Muijtjens M, Kobayashi K, Takano R, Kanno S-I, Takao M, de Wit J, Verkerk A, Eker A, van Leenen D, Buijs R, Bootsma D, Hoeijmakers J, Yasui A. Mammalian cry1 and cry2 are essential for maintenance of circadian rhythms. Nature 1999, 398: 627-630.

[28] Griffin EA Jr, Staknis D, Weitz CJ. Lightindependent role of CRY1 and CRY2 in the mammalian circadian clock. Science 1999, 286: 768-771.

[29] Kume K, Zylka M, Sriram S, Shearman L, Weaver D, Jin X, Maywood E, Hasting M, Reppert S. mCRY1 and mCRY2 are essential components of the negative limb of the circadian clock feedback loop. Cell 1999, 98: 193-205.

[30] Brown SA, Ripperger J, Kadener S, FleuryOlela F, Vilbois F, Rosbash M, Schibler U. PERIOD1-associated proteins modulate the negative limb of the mammalian circadian oscillator. Science 2005, 308: 693-696.

[31] Shearman L, Sriram S, Weaver D, Maywood E, Chaves I, Zheng B, Kume $\mathrm{K}$, Lee C, van der Horst G, Hastings M, Reppert S. Interacting molecular loops in the mammalian circadian clock. Science 2000, 288: 1013-1019.

[32] Vielhaber E, Eide E, Rivers A, Gao Z-H, Virshup D. Nuclear entry of the circadian regulator mPER1 is controlled by mammalian casein kinase I epsilon. Mol Cell Biol 2000, 20: 4888-4899.

[33] Camacho F, Cilio M, Guo Y, Virshup DM, Patel K, Khorkova O, Styren S, Morse B, Yao Z, Keesler GA. Human casein kinase Idelta phosphorylation of human circadian clock proteins period 1 and 2. FEBS Lett 2001, 489: 159-165.

[34] Eide EJ, Vielhaber EL, Hinz WA, Virshup DM. The circadian regulatory proteins BMAL1 and cryptochromes are substrates of casein kinase I epsilon. J Biol Chem 2002, 277: 17248-17254.

[35] Akashi M, Tsuchiya Y, Yoshino T, Nishida E. Control of intracellular dynamics of mammalian Period proteins by casein kinase I epsilon (CKIe) and CKIdelta in cultured cells. Mol Cell Biol 2002, 22: 1693-1703.

[36] Lee C, Weaver D, Reppert SM. Direct association between mouse PERIOD and CKIepsilon is critical for a functioning circadian clock. Mol Cell Biol 2004, 24: 584-594.

[37] Sato TK, Panda S, Miraglia LJ, Reyes TM, Rudic RD, McNamara P, Nalk KA, FitzGerald GA, Kay SA, Hogenesch JB. A functional genomics strategy reveals Rora 
as a component of the Mammalian circadian clock. Neuron 2004, 43: 527-537.

[38] Preitner N, Damiola F, Lopez-Molina L, Zakany J, Duboule D, Albrecht U, Schibler U. The orphan nuclear receptor REVERBalpha controls circadian transcription within the positive limb of the mammalian circadian oscillator. Cell 2002, 110: 251-260.

[39] Honma S, Kawamoto T, Takagi Y, Fujimoto K, Sato F, Noshiro M, Kato Y, Honma K. Dec1 and Dec2 are regulators of the mammalian molecular clock. Nature 2002, 419: 841-844.

[40] Hamaguchi H, Fujimoto K, Kawamoto T, Noshiro M, Maemura K, Takeda N, Nagai R, Furukawa M, Honma S, Honma K, Kurihara H. Expression of the gene for Dec2, a basic helix-loop-helix transcription factor, is regulated by a molecular clock system. Biochem J 2004, 382: 43-50.

[41] Sato F, Kawamoto T, Fujimoto K, Noshiro M, Honda KK, Honma S, Honma K, Kato Y. Functional analysis of the basic helixloop-helix transcription factor DEC1 in circadian regulation. Eur J Biochem 2004, 271: 4409-4419.

[42] Kornmann B, Preitner N, Rifat D, FleuryOlela F, Schibler U. Analysis of circadian liver gene expression by ADDER, a highly sensitive method for the display of differentially expressed mRNAs. Nucleic Acids Res 2001, 29: E51-1.

[43] Storch K-F, Lipian O, Leykin I, Viswanathan N, Davis F, Wong W, Weitz C. Extensive and divergent circadian expression in liver and heart. Nature 2002, 417: $78-83$.

[44] Ueda H, Chen W, Adachi A, Wakamatsu $\mathrm{H}$, Hayashi $\mathrm{S}$, Takasugi $\mathrm{T}$, Nagano $\mathrm{M}$, Nakahalma K-I, Suzuki Y, Shigeyoshi Y, Hashimoto S A transcriptional factor response element for gene expression during circadian night. Nature 2002, 418: 534-538.

[45] Panda S, Antoch M, Miller B, Su A, Schook A, Schultz P, Kay S, Takahashi J, Hogenesh J. Coordinated transcription of key pathways in the mouse by the circadian clock. Cell 2002, 109: 307-320.

[46] Duffield GE. DNA Microarray analyses of circadian timing: the genomic basis of biological time. J Neuroendocrinol 2003, 15: 991-1002.
[47] Oishi K, Sakamoto K, Okada T, Nagase T, Ishida N. Antiphase circadian expression between BMAL1 and period homologue mRNA in the suprachiamastic nucleus and peripheral tissues of rats. Biochem Biophys Res Commun 1998, 253: 199-203.

[48] Oishi K, Sakamoto K, Okada T, Nagase T, Ishida N. Humoral signals mediate the circadian expression of rat period homologue (rPer2) mRNA in peripheral tissues. Neurosci Lett 1998, 256: 117-119.

[49] Oishi K, Miyasaki K, Kadoka K, Kikuno R, Nagase T, Atsumi G-I, Ohkura N, Azama T, Mesaki M, Yukimasa S, Kobayashi H, Iitaka C, Umehara T, Horikoshi Y, Kudo T, Shimizu Y, Yano M; Monden M, Machida $\mathrm{K}$, Matsuda J, Horie S, Todo T, Ishida $\mathrm{N}$. Genome-wide expression analysis of mouse liver reveals CLOCK-regulated circadian ouput genes. J Biol Chem 2003, 42: 41519-41527.

[50] Bae K, Jin X, Maywood ES, Hastings MH, Reppert SM, Weaver DR. Differential functions of mPer1, mPer2, and mPer3 in the SCN circadian clock. Neuron 2001, 30: 525-536.

[51] Zheng B, Larkin DW, Albrecht U, Sun ZS, Sage M, Eichele G, Lee CC, Bradley A. The mPER2 gene encodes a functional component of the mammalian circadian clock. Nature 1999, 400: 169-173.

[52] Zheng B, Albrecht U, Kaasik K, Sage M, Lu W, Vaishnav S, Li Q, Sun Z S, Eichele G, Bradley A, Lee C C. Nonredundant roles of the mPer1 and mPer2 genes in the mammalian circadian clock. Cell 2001, 105: 683-694.

[53] Lee C, Etchegaray J-P, Cagampang FRA, Loudon ASI, Reppert SM. Posttranslational mechanisms regulate the mammalian circadian clock. Cell 2001, 107: 855-867.

[54] Yu W, Nomura M, Ikeda M. Interactivating feedback loops within the mammalian clock: BMAL1 is negatively autoregulated and upregulated by CRY1 CRY2 and PER2. Biochem Biophys Res Commun 2002, 290 : 933-941.

[55] Fu L, Pelicano H, Liu J, Huang P, Lee CC The circadian gene Period 2 plays an important role in tumor suppression and DNA damage response in vivo. Cell 2002, 111: 41-50.

[56] Fu L, Patel MS, Bradley A, Wagner EF, Karsenty G. The molecular clock mediates 
leptin-regulated bone formation. Cell 2005, 122: 803-815.

[57] Motzkus D, Maronde E, Grunenberg U, Lee C, Forssmann W-G, Albrecht U. The human PER1 gene is transcriptionally regulated by multiple signaling pathways. FEBS Lett 2000, 486: 315-319.

[58] Motzkus D, Albrecht U, Maronde E The human PERI gene is inductible by interleukin-6. J Mol Neurosci 2002, 218: 105-109.

[59] Yamamoto T, Nakahata Y, Tanaka M, Yoshida M, Soma H, Shinohara K, Yasuda A, Mamine T, Takumi T. Acute physical stress elevates mouse Period1 mRNA expression in mouse peripheral tissues via a Glucocorticoid-responsive element. J Biol Chem 2005, 280: 42036-42043.

[60] Brown SA, Fleury-Olela F, Nagoshi E, Hauser C, Juge C, Meier CA, Chicheportiche R, Dayer J-M, Schibler U. The Period length of fibroblast circadian gene expression varies widely among human individuals. PLOS Biology 2005, 3: 1813-1818.

[61] Scheving LA. Biological clocks and the digestive system. Gastroenterology 2000, 119: 536-549.

[62] Rivkees SA. Developing circadian rhythmicity in infants. Pediatrics 2003, 112: 373-381.

[63] Seron-Ferré M, Torres C, Parraguez VH, Vergara M, Valladares L, Forcelledo ML, Constandil L, Valenzuela GJ. Perinatal neuroendocrine regulation. Development of the circadian time-keeping system. Mol Cell Endocrinol 2002, 186: 169-173.

[64] Weinert D. Ontogenetic development of the mammalian circadian system. Chronobiol Int 2005, 22: 179-205.

[65] Yan L, Takekida S, Shigeyoshi Y, Okamura $H$. Per1 and Per2 gene expression in the rat suprachiasmatic nucleus: circadian profile and the compartment-specific response to light. Neuroscience 1999, 94: 141-150.

[66] Sladek M, Sumova A, Kovacikova Z, Bendova $Z$, Laurinova $K$, Illnerova $\mathrm{H}$. Insight into molecular core clock mechanism of embryonic and early postnatal rat suprachiasmatic nucleus. Proc Natl Acad Sci USA 2004, 101: 6231-6236.

[67] Hastings MH, Herzog ED. Clock genes, oscillators, and cellular networks in the suprachiasmatic nuclei. J Biol Rhythms 2004, 19: 400-413.

[68] La Fleur SE. Daily rhythms in glucose metabolism: suprachiasmatic nucleus output to peripheral tissue. J Neuroendocrinol 2003, 15: 315-322.

[69] Oishi K, Fukui H, Sakamoto K, Miyazaki K, Kobayashi H, Ishida N. Differential expression of mPer1 and mPer2 mRNAs under a skeleton photoperiod and a complete light-dark cycle. Mol Brain Res 2002, 109: 11-17.

[70] Barinaga M. Setting the human clock: technique challenged. Science 2002, 297: 505.

[71] Pando MP, Morse D, Cermakian N, Sassone-Corsi P. Phenotypic rescue of a peripheral clock genetic defect via SCN hierarchical dominance. Cell 2002, 110: 107-117.

[72] Balsalobre A, Marcacci L, Schibler U. Multiple signaling pathways elicit circadian gene expression in cultured Rat-1 fibroblasts. Curr Biol 2000, 10: 1291-1294.

[73] Balsalobre A, Brown SA, Marcacci L, Tronche F, Kellendock C, Reichardt HM, Schütz G, Schibler U. Resetting of circadian time in peripheral tissues by glucocorticoid signaling. Science 2000, 289: 2344-2347.

[74] McNamara P, Seo S-B, Rudi R, Seghal A, Chakravarti G. Regulation of CLOCK and MOP4 by nuclear hormone receptor in the vasculature: a humoral mechanism to reset a peripheral clock. Cell 2001, 105: 877-889.

[75] Pévet P. Identification d'un nouveau signal de l'horloge circadienne chez les mammifères: le TGF-alpha. Médecine/Science 2002, 18: 1103-1106.

[76] Kramer A, Yang F-C, Snodgrass P, Li X, Scammell T, Davis F, Weitz C. Regulation of daily locomotor activity and sleep by hypothalamic EGF receptor signaling. Novartis Foundation Symp 2003, 253: 250-262.

[77] Cheng MY, Bullock CM, Li C, Lee AG, Bermak JC, Belluzzi J, Weaver DR, Leslie FM, Zhou Q-Y. Prokineticin 2 transmits the behavioural circadian rhythm of the suprachiasmatic nucleus. Nature 2002, 417: 405-410.

[78] Kita Y, Shiozawa M, Jin W, Majewski $\mathrm{R}$, Besharse J, Greene A, Jacob $\mathrm{H}$. 
Implications of circadian gene expression in kidney, liver and the effects of fasting on pharmacogenomic studies. Pharmacogenetics 2002, 12: 55-65.

[79] Le Minh N, Damiola F, Tronche F, Schutz G, Schibler U. Glucocorticoid hormones inhibit food-induced phase-shifting of peripheral circadian oscillators. EMBO J 2001, 20: 7128-7136.

[80] Yagita K, Tamanini F, van der Horst G, Okamura H. Molecular mechanisms of the biological clock in cultured fibroblasts. Science 2001 292: 278-281.

[81] Reppert S, Weaver R. Coordination of circadian timing in mammals. Nature 2002, 418: 935-941.

[82] Davidson AJ, Poole AS, Yamazaki S, Menaker M. Is the food-entrainable circadian oscillator in the digestive system? Genes Brain Behav 2003, 2: 32-39.

[83] Schibler U, Sassone-Corsi P. A web of circadian pacemakers. Cell 2002, 111: 919-922.

[84] Schibler U, Ripperger J, Brown SA. Peripheral circadian oscillators in Mammals: time and food. J Biol Rhythms 2003, 18: 250-260.

[85] Bjarnason GA, Jordan RCK, Wood PA, Li Q, Lincoln DW, Sothern RB, Hrushesky WJM, Ben-David Y. Circadian expression of clock genes in human oral mucosa and skin. Association with specific cellcycle phases. Am J Pathol 2001, 158: $1793-1801$

[86] Sakamoto K, Nagase T, Fukui H, Horikawa K, Okada T, Tanaka H, Sato K, Miyake Y, Ohara O, Kako K, Ishida N. Multitissue circadian expression of rat period homolog (rPer2) mRNA is governed by the mammalian circadian clock the suprachiasmatic nucleus in the brain. J Biol Chem 1998, 273: 27039-27042.

[87] Damiola F, Le Minh N, Preitner N, Kornmann B, Fleury-Olela F, Schiebler U. Restricted feeding uncouples circadien oscillators in peripheral tissues from the central pacemaker in the suprachiasmatic nucleus. Genes Dev 2000, 14: 2950-2961.

[88] Pardini L, Kaeffer B, Trubuil A, Bourreille A, Galmiche J-P, Cherbut C. Period-1 and Period-2 protein expression by human colonocytes. 1st World Congress on Chronobiology, September 9-12, 2003. Sapporo, Japan.
[89] Pardini L, Kaeffer B, Trubuil A, Bourreille A, Galmiche J-P. Human intestinal circadian clock: expression of clock genes in colonocytes lining the crypt. Chronobiol Int, 2005, 6: 951-961.

[90] Buchi KN, Moore JG, Hrushesky WJM, Sothern RB, Rubin NH. Circadian rhythm of cellular proliferation in the human rectal mucosa. Gastroenterology 1991, 101: 410-415.

[91] Marra G, Anti M, Percesepe A, Armelao F, Ficarelli R, Coco C, Rinelli A, Vecchio FM, D'Arcangelo E. Circadian variations of epithelial cell proliferation in human rectal crypts. Gastroenterology 1994, 106: 982-987.

[92] Qiu JM, Roberts SA, Potten CS. Cell migration in the small and large bowel shows a strong circadian rhythm. Epithelial Cell Biol 1994, 3: 137-148.

[93] Iwakiri R, Gotoh Y, Noda T, Sugihara $\mathrm{H}$, Fujimoto $\mathrm{K}$, Fuseler J, Aw TY Programmed cell death in rat intestine: effect of feeding and fasting. Scand $\mathrm{J}$ Gastroenterol 2001, 36: 39-47.

[94] Abizaid A, Mezei G, Sotonyi P, Horvath TL. Sex differences in adult suprachiamastic nucleus neurons emerging late prenatally in rats. Eur J Neurosci 2004, 19: 2488-2490.

[95] Carskadon MA, Wolfson AR, Acebo C Tzischinsky O, Seifer R. Adolescent sleep patterns, circadian timing, and sleepiness at a transition to early school days. Sleep 1998, 21: 871-881.

[96] Yamazaki S, Straume M, Tei H, Sakaki Y, Menaker M, Block GD. Effects of aging on central and peripheral mammalian clocks. Proc Natl Acad Sci USA 2002, 99: 10801-10806.

[97] Claustrat F, Fournier I, Geelen G, Brun J, Corman B, Claustrat B. Vieillissement et expressions des gènes de l'horloge circadienne dans les tissus périphériques chez le rat. Aging and circadian clock gene expression in peripheral tissues in rats. Pathol Biol 2005, 318: 1-4.

[98] Czeisler CA, Duffy JF, Shanahan TL, Brown EN, Mitchell JF, Rimmer DW, Ronda JM, Silva EJ, Allan JS, Emens JS, Dijk D-J, Kronauer RE. Stability, precision, and near-24-h period of the human circadian pacemaker. Science 1999, 284: 2177-2181. 
[99] Ruby NF, Burns DE, Heller HC. Circadian rhythms in the suprachiasmatic nucleus are temperature-compensated and phaseshifted by heat pulses in vitro. J Neurosci 1999, 19: 8630-8636.

[100] Brown SA, Zumbrunn G, Fleury-Olela F, Preitner N, Schibler U. Rhythms of mammalian body temperature can sustain peripheral circadian clocks. Curr Biol 2002 , 12: 1574-1583.

[101] Tsuchiya Y, Akashi M, Nishida E Temperature compensation and temperature resetting of circadian rhythms in mammalian cultured fibroblasts. Genes Cells 2003, 8: 713-720.

[102] Johnson B. Nutrient intake as a time signal for circadian rhythm. J Nutr 1992, 122: 1753-1759.

[103] Stephan K. The "other" circadian system: food as zeitgeber. J Biol Rhythms 2002, 17: 284-292.

[104] Reinberg A, Portero P, Libert J-P. Chronobiologie veille-sommeil et nutrition. Lettre Scientifique de l'IFN, Juin 1995, p 36.

[105] Stephan FK. Calories affect zeitgeber properties of the feeding entrained circadian oscillator. Physiol Behav 1997, 62: 995-1002.

[106] Davidson AJ, Aragona BJ, Werner RM, Schroeder E, Smith JC, Stephan FK. Foodanticipatory activity persists after olfactory bulb ablation in the rat. Physiol Behav 2001, 72: 231-235.

[107] Mistleberger RE, Skene DJ. Social influences on mammalian circadian rhythms: animal and human studies. Biol. Rev. 2004 79: $533-556$

[108] Challet E, Malan A, Pévet P. Daily hypocaloric feeding entrains circadian rhythms of wheel-running and body temperature in rats kept in constant darkness. Neurosci Lett 1996, 211: 1-4.

[109] Lax P, Zamora S, Madrid J. Food-entrained feeding and locomotor circadian rhythms in rats under different lighting conditions. Chronobiol Int 1999, 16: 281-291.

[110] Hara R, Wan K, Wakamatsu H, Aida $\mathrm{R}$, Moriya $\mathrm{T}$, Akiyama M, Shibata S. Restricted feeding entrains liver clock without participation of the suprachiasmatic nucleus. Genes Cells 2001, 6: 269-278.
[111] Wakamatsu H, Yoshinobu Y, Aida R Moriya T, Akiyama M, Shibata S. Restricted-feeding-induced anticipatory activity rhythm is associated with phaseshift of the expression of mPer1 and mPer2 mRNA in the cerebral cortex and hippocampus but not in the suprachiasmatic nucleus of mice. Eur J Neurosci 2001, 13: 1190-1196.

[112] Stokkan KA, Yamazaki S, Tei H, Sakaki Y, Menaker M. Entrainment of the circadian clock in the liver by feeding. Science 2001 , 291: 490-493.

[113] Davidson AJ, Stephan FK. Circadian food anticipation persists in capsaicin deafferented rats. J Biol Rhythms 1998, 13: 422-429.

[114] Pitts SN, Perrone E, Silver R. Foodentrained circadian rhythms are sustained in arrhythmic clk/clk mutant mice. Am J Physiol (Regulatory Integrative and Comparative Physiology) 2003, 285: R57-R67.

[115] Miki H, Yano M, Iwanaga H, Tsujinaka T, Nakayama M, Kobayashi M, Oishi K, Shiozaki H, Ishida N, Nagai K, Monden M. Total parenteral nutrition entrains the central and peripheral circadian clocks. NeuroReport 2003, 14: 1457-1461.

[116] Reinberg A, Chaumont A, Laporte A. Étude chronobiologique des changements d'horaires du travail (autométrie de 20 sujets postés: système des $3 \times 8$ à rotation hebdomadaire). Arch Mal Prof 1973, 35: 373-394.

[117] Iraki L, Bogdan A, Hakkou F, Amrani N, Abkari A, Touitou Y. Ramadan diet restriction modify the circadian time structure in humans. A study on plasma gastrin insulin glucose and calcium and on gastric pH. J Clin Endocrinol Metab 1997, 82: 1261-1273.

[118] Bogdan A, Bouchareb B, Touitou Y. Ramadan fasting alters endocrine and neuroendocrine circadian patterns. Meal-time as a synchronizer in humans? Life Sciences 2001, 68: 1607-1615.

[119] Krauchi K, Cajochen C, Werth E, WirzJustice A. Alteration of internal circadian phase relationships after morning versus evening carbohydrate-rich meals in humans. J Biol Rhythms 2002, 17: 364-376.

[120] Kolker DE, Losee Olson S, Dutton-Bollek J, Bennett KM, Wallen EP, Horton TH, 
Turek FW. Feeding melatonin enhances the phase shifting response to triazolam in both young and old golden hamsters. Am J Physiol 2002, 282: R1382-R1388.

[121] Mendoza J, Graff C, Dardente H, Pévet P, Challet E. Feeding cues alter clock gene oscillations and photic responses in the suprachiasmatic nuclei of mice exposed to light/dark cycle. J Neurosci 2005, 25: 1514-1522.

[122] Challet E, Solberg L, Turek F. Entrainment in calorie-restricted mice: conflicting zeitgebers and free-running conditions. Am J Physiol 274 1998, 274: R1751-R1761.

[123] Stephan FK, Davidson AJ. Glucose but not fat phase shifts the feeding-entrained circadian clock. Physiol Behav 1998, 65: 277-288.

[124] Challet E, Kolker DE, Turek FW. Metabolic influences on circadian rhythmicity in Siberian and Syrian hamsters exposed to long photoperiods. J Neuroendocrinol 2000, 12: 69-78.

[125] Challet E, Pévet P, Vivien-Roels B, Malan A. Phase-advanced daily rhythms of melatonin, body temperature, and locomotor activity in food-restricted rats fed during daytime. J Biol Rhythms 1997, 12: 65-79.

[126] Challet E, Caldelas I, Graff C, Pévet P. Synchronization of the molecular clockwork by light- and food-related cues in mammals. Biol Chem 2003, 384: 711-719.

[127] Challet E, Takahashi JS, Turek FW. Nonphotic phase-shifting in clock mutant mice. Brain Res 2000, 859: 398-403.

[128] Turek FW, Joshu C, Kohsaka A, Lin E, Ivanova $\mathrm{G}$, McDearmon E, Laposky A, Losee-Olson S, Easton A, Jensen DR, Eckel RH, Takahashi JS, Bass J. Obesity and metabolic syndrome in circadian clock mutant mice. Science 2005, 308: 1043-1045

[129] Akhtar RA, Reddy AB, Maywood ES, Clayton JD, King VM, Smith AG, Gant TW, Hastings M, Kyriacou CP. Circadian cycling of the mouse liver transcriptome as revealed by cDNA microarray is driven by the suprachiasmatic nucleus. Curr Biol 2002, 12: 540-550.

[130] Challet E, Losee-Olson S, Turek F. Reduced glucose availability attenuates circadian responses to light in mice. Am J Physiol 1999, 276: R1063-R1070.

[131] Rutter J, Reick M, Wu L C, McKnight S L. Regulation of Clock and NPAS2 DNA binding by the Redox state of NAD cofactors. Science 2001, 293: 510-514.

[132] Rutter J, Reick M, McKnight S L. Metabolism and the control of circadian rhythms. Annu Rev Biochem 2002, 71: 307-331.

[133] Hirota T, Okano T, Kokame K, ShirotaniIkejima H, Miyata T, Fukuda Y. Glucose down-regulates Per1 and Per2 mRNA levels and induces circadian gene expression in cultured Rat-1 fibroblasts. The J Biol Chem 2002, 277: 44244-44251.

[134] Pardini L, Kaeffer B, Trubuil A, Bourreille A. Serum-induced expression of proteins regulating the circadian rhythm in human colon cancer cell lines: implications for primary culture. World Congress on In Vitro Biology 2004, Abstract issue, VT-1006.

[135] Cherbuy C, Darcy-Vrillon B, Morel M-T, Pégorier J-P, Duée P-H. Effect of germfree state on the capacities of isolated rat colonocytes to metabolize n-butyrate, glucose, and glutamine. Gastroenterology 1995, 109: 1890-1899.

[136] Le Bacquer O, Laboisse C, Darmaun D. Glutamine preserves protein synthesis and paracellular permeability in $\mathrm{CaCo}-2$ cells submitted to "luminal fasting". Am J Physiol Gastrointest Liver Physiol 2003, 285: G1-G9.

[137] Toh K, Jones C, He Y, Eide E, Hinz W, Virshup D, Ptacek L, Fu Y. An hPer2 phosphorylation site mutation in familial advanced sleep phase syndrome. Science 2001, 291: 1040-1043.

[138] Xu Y, Padiath QS, Shapiro RE, Jones CR, Wu SC, Saigoh N, Saigoh K, Ptacek $\mathrm{LJ}, \mathrm{Fu}$ Y-H. Functional consequences of a CKIdelta mutation causing familial advanced sleep phase syndrome. Nature 2005, 434: 640-644.

[139] Ebisawa T, Uchiyama M, Kajimura N, Mishima K, Kamei Y, Katoh M, Watanabe T, Sekimoto M, Shibui K, Kim K, Kudo Y, Ozeki Y, Sugishita M, Toyoshima R, Inoue Y, Yamada N, Nagase T, Ozaki N, Ohara O, Ishida N, Okawa M, Takahashi K, Yamauchi T. Association of structural polymorphisms in the human period3 gene with delayed sleep phase syndrome. EMBO report 2001, 2: 342-346.

[140] Archer SN, Robilliard DL, Skene DJ, Smits M, Williams A, Arendt J, von Schantz M. A length polymorphism in the circadian clock 
gene Per3 is linked to delayed sleep phase syndrome and extreme diurnal preference. Sleep 2003, 26: 413-415.

[141] Katzenberg D, Young T, Finn L, Lin L, King DP, Takahashi JS, Mignot E. A CLOCK polymorphism associated with human diurnal preference. Sleep 1998, 21: 569-576.

[142] Kennaway DJ. Programming of the fetal suprachiasmatic nucleus and subsequent adult rhythmicity. Trends Endocrinol Metab 2002, 13: 398-402.

[143] Rajaratnam S, Arendt J. Health in a 24-h society. Lancet 2001, 358: 999-1005.

[144] Kawamura H, Ibuka N. The search for circadian rhythm pacemarkers in the light of lesion. Chronobiologia 1978, 5: 69-88.

[145] Nagai K, Nishio T, Nakagawa H, Nakamura S, Fukuda Y. Effect of bilateral lesions of the suprachiasmatic nuclei on the circadian rhythm of food-intake. Brain Res 1978, 142: 384-389.

[146] Nishio T, Shiosaka S, Nakagawa $H$, Sakumuto T, Satoh K. Circadian feeding rhythm after hypothalamic knife-cut isolating suprachiasmatic nucleus. Physiol Behav 1979, 23: 763-769.

[147] Boulos Z, Rosenwasser AM, Terman M. Feeding schedules and the circadian organization of behaviour in the rat. Brain Res 1980, 1: 39-56.

[148] Füller CA, Sulzman FM, Moore-Ede MC. Role of heat loss and heat production in generation of the circadian temperature rhythm of the squirrel monkey. Physiol Behav 1985, 34: 543-546.

[149] Fu Y, Zhong H, Wang MHH, Luo DG, Liao HW, Maeda H, Hattar S, Frishman LJ, Yau KW. Intrinsically photosensitive retinal ganglion cells detect light with a vitamin Abased photopigment, melanopsin. Proc Natl Acad Sci USA 2005, 102: 10339-10344.

To access this journal online: www.edpsciences.org/rnd 